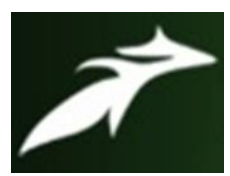

G. I. Harry et al, International Journal of Advances in Agricultural Science \& Technology,

Vol.9 Issue.1, January-2022, pg. 22-36

ISSN: 2348-1358

Impact Factor: 6.846

NAAS Rating: 3.77

\title{
Evaluation of Orange Fleshed Sweetpotato (Ipomoea batatas (L.) Lam) Genotypes for Growth and Yield related Characters under Rainfed Condition in Uyo Southeastern Nigeria
}

\author{
G. I. Harry ${ }^{1}$; J. I. Ulasi ${ }^{1 *}$ \\ ${ }^{1}$ Department of Crop Science, Faculty of Agriculture, University of Uyo, \\ ${ }^{1}$ P.M.B 1017, Uyo, Akwa, Ibom State, Nigeria \\ *Corresponding author's e-mail: joeulasi@gmail.com; ifeanyijoseph@uniuyo.edu.ng \\ DOI: 10.47856/ijaast.2022.v09i01.003
}

\begin{abstract}
Five orange fleshed sweetpotato (Ipomoea batatas (L.) Lam) genotypes sourced from National Root Crops Research Institute, Umudike were evaluated under rainfed condition in 2020 and 2021 cropping seasons at the Teaching and Research Farm of the University of Uyo, Uyo, Akwa Ibom State, Nigeria to identify the high yielding and adaptable genotypes. The five genotypes; Umuspo-3, Umuspo-1, Naspot-12, Lourdes and Erica were used as treatments and the experiment was laid out in a randomized complete block design with three replications. Data on growth, yield and yield related characters were collected and analysis of variance, correlation and principal component analysis were performed. The result of the study indicated that the genotype differ significantly $(\mathrm{P} \leq 0.05)$ for number of marketable roots, weight of marketable roots and fresh roots yield. Umuspo-3 produced the highest storage root yield $(29.22 \mathrm{t} / \mathrm{ha}$, $28.78 \mathrm{t} / \mathrm{ha}$ ) in 2020 and 2021 cropping seasons, respectively. The result of the correlation analysis also revealed that vine length, number of marketable roots, weight of marketable were highly significantly and positively $(\mathrm{P} \leq 0.01)$ correlated with fresh root yield. Principal component analysis (PCA) had three main principal components explaining $82.41 \%$ of the total variation with number of marketable roots, weight of marketable tuber and storage root yield contributing the most to the first PCA. Umuspo-3 recorded high yield than the other four orange-fleshed sweetpotato. Therefore, Umuspo-3 was identified as a high yielding and adaptable orangefleshed sweetpotato genotype and could be recommended mass cultivation in Uyo agro-ecology as a high yielding orange-fleshed sweetpotato.
\end{abstract}

Keywords: Growth, Orange fleshed sweetpotato, Fresh root yield, Uyo, Vitamin A 


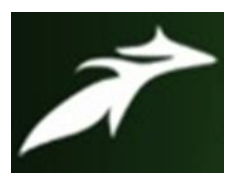

G. I. Harry et al, International Journal of Advances in Agricultural Science \& Technology, Vol.9 Issue.1, January-2022, pg. 22-36

ISSN: 2348-1358

Impact Factor: 6.846

NAAS Rating: 3.77

\section{INTRODUCTION}

Sweetpotato (Ipomoea batatas (L.) Lam) is a dicotyledonous tuber belonging to the morning glory family; Convolvulaceae and it is an important stable crop that is consumed in many developing countries in the tropics (Thottappilly and Loebenstein, 2009). Sweetpotato is cultivated the different continents of the world on approximately 8.21 million hectare (ha) with an estimated annual yield of 104.02 million tonnes (FAOSTAT, 2014). The nutritional content of sweetpotato is enriched with a protein above that of other tuber crops, namely; cassava and yam as well as carotenes, which is a useful source of vitamin A (Mukhtar et al., 2010). Majority of sweetpotato farmers in Nigeria are small holder farmers, whose preference for the crop is largely due to its short gestation period of about four to five months, depending on the variety and it ability to survive on different ecology types (Antiaonong and Bassey, 2008). It is a crop that survives under environmental stress conditions and could be cultivated on soils with minimal fertility status, thus making it a reliable crop that has the potential to combat food security problems in the Sub-Saharan Africa. In the tropics, the average yield potential of sweetpotato ranges from $20-50 \mathrm{t} / \mathrm{ha}$ and the annual world production is 131 million tons, on approximately 9 million hectares with mean estimated yields of 13.7 t/ha. In Nigeria, however, farmers have recorded one of the world's lowest average sweetpotato yield of $3 \mathrm{t} / \mathrm{ha}$ (FAO, 2015). Sweetpotato produces high yield per area (Nwankwo et al., 2012). White fleshed sweetpotato varieties are predominately cultivated and consumed and these white fleshed varieties containing a minimal quantity of beta carotene. A major improvement of the sweetpotato breeding is the development of the Orange Fleshed Sweetpotato (OFSP) varieties, which are enriched with significant quantity of beta carotene that the human body system utilizes to produce vitamin A (Wariboko and Ogidi, 2014). Beta carotene is a major source of vitamin A, which is remedy for vitamin A deficiency (Omiat et al., 2005). In developing countries, including Nigeria, vitamin A deficiency is a prevalent condition with adverse health implications on young children. OFSP varieties are affordable and constant source of dietary vitamin A (Omiat et al., 2005) to the poor and malnourished families in developing countries, including (Low et al., 2007). Generally, sweetpotato is widely accepted and consumed in Akwa Ibom State but its production and supply is not commensurate with the rate of consumption, since it is not extensively cultivated. Akwa Ibom State is among the least sweetpotato producing states in Nigeria and the local demands is only satisfied by imports from other states in Nigeria (Roberts, 2012). Presently, the rate of production and consumption of OFSP is abysmally low, hence the need to popularized OFSP in the state, considering its tremendous health benefits. Identification of suitable OFSP genotypes from already existing germplasm could contribute immensely to the improvement of sweetpotato, especially, if their physiological characters and yield components correlate with tuber yield (Gargi et al., 2013). Therefore, the objective of this experiment was to identify promising and adaptable orange fleshed sweetpotato genotypes in terms of yield and yield component parameters and hence could remedy Vitamin A Deficiency (VAD) in Akwa Ibom State, Southeastern Nigeria. 


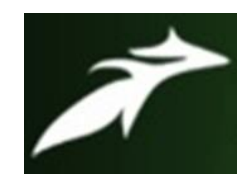

G. I. Harry et al, International Journal of Advances in Agricultural Science \& Technology, Vol.9 Issue.1, January-2022, pg. 22-36

ISSN: 2348-1358

Impact Factor: 6.846

NAAS Rating: 3.77

\section{MATERIALS AND METHODS}

Experimental site and field layout

The present study was conducted at the University of Uyo Teaching and Research Farm in Uyo, Akwa Ibom State, Nigeria during 2020 and 2021 early cropping seasons. Uyo is located in the south-south part of Nigeria and is situated within the humid tropical rainforest zone. The area lies within latitude $4^{\circ} 33^{\prime}$ and $5^{\circ} 33^{\prime}$ North and longitude $7^{\circ} 55^{\prime}$ and $8^{\circ} 25^{\prime}$ East of the Greenwich meridian. The mean annual rainfall ranges from $2680.8-2700.1 \mathrm{~mm}$ with a mean monthly relative humidity of $79.8 \%$ while the mean monthly atmospheric temperature range is $26.88-$ $27.00^{\circ} \mathrm{C}$ (Ndaeyo, 2003). The field experiment was laid out in a randomized complete block design (RCBD) with three replications per treatment. Each replication was marked out into plots of $6 \mathrm{~m}^{2}(2 \mathrm{~m} \times 3 \mathrm{~m})$. There were 5 plots per block and the total land size of $94 \mathrm{~m}^{2}$.

\section{Planting materials}

The planting materials (treatments) were five (5) genotypes of sweetpotato; Umuspo-3, Umuspo1, Erica, Naspot-12 and Lourdes obtained from National Root Crops Research Institute (NRCRI), Umudike, Abia State, Nigeria.

\section{Agronomic practices}

The land was mechanically ploughed, harrowed and ridged $1 \mathrm{~m}$ apart. The plots were marked out using measuring tape, pegs and ropes. Sweetpotato vines were cut $25 \mathrm{~cm}$ long with four nodes. The vine cuttings were sown $30 \mathrm{~cm}$ intra-row and $100 \mathrm{~cm}$ inter-row on the crest of ridges, and $10 \mathrm{~cm}$ below the soil surface on raised beds. Poultry manure was incorporated at a recommended rate of 8.6t/ha two weeks before planting (County, 1996). Organic manure (poultry dung) should be incorporated into the soil during land preparation for sweetpotato production when the soil is found to be of low fertility status (Saviour et al., 2013). Planting was done on $21^{\text {st }}$ May, 2020 and $21^{\text {st }}$ May, 2021, using 10 vines per plot. The crop were rain-fed. Weeding was done at 4, 8 and 12 weeks after planting (WAP). Fertilizer (NPK: 15:15:15) was applied 400kg//ha 4 weeks after planting (WAP), immediately after first weeding (Nwankwo et al., 2012). Five plants per plot were randomly selected and tagged for data collection. Data on growth parameters was collected at $6^{\text {th }}$, 9th and $12^{\text {th }}$ week respectively. Growth parameters include; vine length, vine girth, number of branches, leaf area, number of leaves. Harvesting was done 120 days after planting (DAP). Each plots were harvested by uprooting six plants from the middle of each plot. Vines were first cut with cutlasses and the storage roots were uprooted with fork. Harvest data were taken on the following characters; number of marketable, non-marketable tubers per plot, marketable root weight $(\mathrm{kg} / \mathrm{ha})$, unmarketable root weight $(\mathrm{kg} / \mathrm{ha})$ and fresh root yield $(\mathrm{t} / \mathrm{ha})$. 


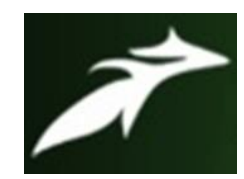

G. I. Harry et al, International Journal of Advances in Agricultural Science \& Technology, Vol.9 Issue.1, January-2022, pg. 22-36

ISSN: 2348-1358

Impact Factor: 6.846

NAAS Rating: 3.77

\section{Statistical Analysis}

Harvest data were collected and introduced into SPSS software (Version 22) for analysis of variance (ANOVA) and mean separation was carried out using the Least Significant Difference (LSD) test at 5\% level of significance. Pearson's correlation analysis was done to show association among yield and yield related components of sweetpotato genotypes. Principal component analysis was done for the yield related traits.

\section{RESULTS AND DISCUSSION}

The results of the current study revealed that some important yield related characters of the evaluated Orange Fleshed Sweetpotatoes (OFSPs) genotypes differed significantly $(\mathrm{p} \leq 0.05)$. The analysis of variance (ANOVA) revealed that some of the growth characters investigated differed significantly among the genotypes $(\mathrm{p} \leq 0.05)$ while some other growth characters did not differ significantly ( $\mathrm{p} \leq 0.05)$ in 2020 and 2021 cropping seasons (Table 2 and 3 ). The current finding is in agreement with Omiat et al. (2005), who indicated that varietal effect had a significant influence on the marketable tuberous root yield as well as total tuberous root yield of sweetpotato. Similarly, Kathabwalika et al. (2013) also observed significant differences in storage root yield among sweetpotato varieties in their trial.

\section{Growth characters:}

Results of the study presented in Tables 2 and 3 showed that significant difference $(\mathrm{p} \leq 0.05)$ was observed among the sweetpotato genotypes for plant height but did not vary significantly ( $\mathrm{p} \leq$ 0.05 ) for vine girth, number of branches, leaf area and number of leaves per plant at 12 week after planting in 2020 and 2021 cropping seasons. In 2020 and 2021 cropping seasons, the longest vine length was produced by Umuspo-3 followed by Erica and Lourdes while the shortest vine length was recorded by Umuspo-1 in 2020 cropping season and Naspot-12 in 2021 cropping season (Tables 2 and 3). In 2020 and 2021 cropping seasons. Umuspo-3 produced the highest vine girth, followed by Naspot-12 while in 2021 cropping season, Umuspo-1 recorded the highest vine girth, followed by Lourdes. In 2020 and 2021 cropping season, Erica recorded the lowest vine girth (Tables 2 and 3$)$. The sweetpotato genotypes differ significantly $(p \leq 0.05)$ in number branches per plant in 2020 cropping season but did not differ significantly $(\mathrm{p} \leq 0.05)$ in 2021 cropping season. In both cropping seasons, Lourdes produced the highest number of branches, followed by Umuspo-3 while the least number of branches was observed with Umuspo-1 in 2020 cropping season and Naspot-12 recorded the least vine length in 2021 cropping season (Table 2 and 3). The largest leaf area per plant was produced by Lourdes, followed by Naspoy-12 respectively, while the smallest leaf area per plant was noticed for Umuspo-3 in 2020 cropping season (Table 2). In 2021 cropping season, the largest leaf area per plant was produced by Lourdes, followed by Umuspo-1 respectively, while the smallest leaf area 


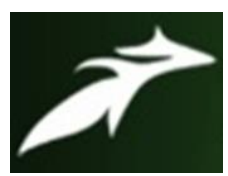

G. I. Harry et al, International Journal of Advances in Agricultural Science \& Technology, Vol.9 Issue.1, January-2022, pg. 22-36

ISSN: 2348-1358

Impact Factor: 6.846

NAAS Rating: 3.77

per plant was noticed for Umuspo-3 (Table 3). The sweetpotato genotypes did not differed significantly $(\mathrm{p} \leq 0.05)$ in number of leaves per plant. In both cropping seasons, Umuspo-3 produced the highest number of leaves. However, the least number of leaves was observed with Umupo-1 in 2020 cropping and Naspot-12 produced the least number of leaves in 2021 cropping season (Table 2 and 3).

\section{Number of marketable root per plot:}

The number of marketable roots per plot in 2020 and 2021 cropping seasons differed significantly ( $\mathrm{p} \leq 0.05)$ among the five sweetpotato genotypes evaluated (Table 2 and Table 3 ). The highest mean number of marketable root per plot $(33.61,34.28)$ was recorded in Umuspo-3 in 2020 and 2021 cropping seasons, respectively. Also, the lowest mean number of marketable roots per plot $(16.95,15.02)$ were recorded by Naspot-12 in both 2020 and 2021 cropping season, respectively (Table 2 and Table 3 ). The difference perceived among the OFSP genotypes in number of marketable roots per plot could be attributed to the differences in their genotypic composition. Umuspo-3 had the highest number of marketable roots per plant and this is one important factor for selection of sweetpotato varieties and serves as indicator of adaptability of the crop to the study area (Nwankwo et al., 2012).

\section{Unmarketable root number and unmarketable root weight:}

In 2020 cropping season, there was no significant difference observed among the OFSP genotypes for unmarketable root number per plot as well as unmarketable root weight per plot. Naspot-12 recorded the highest number of unmarketable root per plot (7.67) while Umuspo-3 recorded the least number of unmarketable roots (5.67) (Table 2). Umuspo-3 recorded the highest unmarketable root weight in 2020 cropping season while Naspot-12 recorded the least weight of unmarketable roots. In 2021 cropping season, there was no significant difference observed among the genotypes for unmarketable root number per plot as well as unmarketable root weight per plot. Naspot-12 recorded the highest number of unmarketable root per plot (6.67) while Umuspo-3 recorded the least number of unmarketable roots (5.33) (Table 3). Umuspo-3 recorded the highest unmarketable root weight in 2021 cropping season while Naspot12 recorded the least weight of unmarketable roots (Table 3). Similarly Nwankwo et al. (2012) also observed none significant differences in number of unmarketable root number per plot among sweetpotato varieties in their study.

Fresh storage root yield:

In both 2020 and 2021 cropping seasons, significant differences were observed among the OFSP genotypes for fresh tuber yield $(\mathrm{t} / \mathrm{ha})$. Umuspo-3 produced the highest storage root yield (29.22t/ha, 28.78t/ha) in both 2020 and 2021 cropping seasons, respectively (Table 2 and Table $3)$. The results further showed that the genotypes Lourdes produced the least storage root yield (8.89t/ha, 9.56t/ha) in 2020 and 2021 cropping seasons, respectively (Table 2 and Table 3). The 


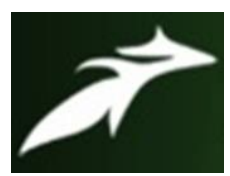

G. I. Harry et al, International Journal of Advances in Agricultural Science \& Technology, Vol.9 Issue.1, January-2022, pg. 22-36

ISSN: 2348-1358

Impact Factor: 6.846

NAAS Rating: 3.77

results showed that Lourdes was generally vegetative and unproductive in both years. The results from both cropping seasons showed that two genotypes out of the five OFSP genotypes evaluated produced tuber yields higher than the world average of $15.9 \mathrm{t} / \mathrm{ha}$, namely Umuspo-3 (28.78t/ha) and Umuspo-1 (16.33t/ha). The current result agrees with the findings of Andrade et al. (2009), who reported that the total storage root yields of five sweetpotato varieties from SubSaharan Africa ranged between 0.5 and $65 \mathrm{t} / \mathrm{ha}$. Consistent with the results of this study, Mcharo and Ndolo (2013) and Nedunchezhiyan et al. (2007) reported large differences between sweetpotato clones in terms of root yield due to genetic variation. Consistent with the results of this study, Wassu et al. (2015) reported significant variations between 116 sweetpotato genotypes that included the genotypes tested in this experiment, with a mean total storage root yield from storage of $10.74(\mathrm{t} / \mathrm{ha}$ ) and a range of 2.26 to $28.46 \mathrm{t} / \mathrm{ha}$. The differences in fresh storage root yield could be attributed to genetic differences among the OFSP varieties (Antiaobong, 2007). This result is agrees with Amare et al. (2014), who also found significant differences in total tuberous root yield among varieties in their trial. Similarly, Wariboko and Ogidi (2014) also concluded that improved OFSP varieties were higher in total tuberous root yield. Based on fresh root yield, Umuspo-3 and Umuspo-1 could be recommended for cultivation in Uyo agro-ecology. For advancement to multi-locational trials, only Umuspo-3 and Umuspo-1 satisfied the selection criteria of securing higher yields. Ragassa et al. (2015) opined that improvement of sweetpotato genotypes can be achieved by crossing with superior genotypes in a given environment. Genotypes with tuber yields below 20t/ha could be crossed with the top yielder (Umuspo-3). The result from the data in this study showed that OFSP genotype Umuspo3 was identified as the high yielding genotype in the study area and can be beneficial to growers aimed at producing sweetpotatoes for tuber production, since yield is an important factor which determines choice of sweetpotato varieties for cultivation (Njoku et al., 2009). However, Kathabwalika et al., (2013) suggested cultivation of the genotypes as forage for ruminants, hence, Lourdes which produced the lowest storage root yield in both cropping seasons cannot fit into cropping systems and therefore should be eliminated from sweetpotato list for the environment for tuber production but recommended for forage production.

\section{Correlation among yield and yield related characters of OFSP genotypes}

In the present study correlation analysis among yield and yield related characters was done and revealed positive and negative associations among the yield and yield related characters of OFSP genotypes evaluated in the study (Table 4). Vine length was positively was significantly and positively correlated $\left(\mathrm{R}=0.60^{*}\right)$ with number of leaves. Vine length was highly significantly and positively correlated $\left(\mathrm{R}=0.86^{* *}\right)$ with number of marketable roots. Storage root yield was positively was highly significantly and positively correlated $(\mathrm{R}=0.72 * *)$ with vine length. Yield was highly significantly and positively correlated $\left(\mathrm{R}=0.84^{* *}\right)$ with number of marketable roots (Table 4). Similarly, yield also highly significantly and positively correlated $(\mathrm{R}=0.99 * *)$ with 


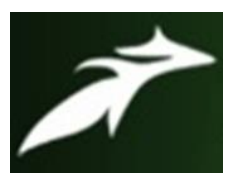

G. I. Harry et al, International Journal of Advances in Agricultural Science \& Technology, Vol.9 Issue.1, January-2022, pg. 22-36

ISSN: 2348-1358

Impact Factor: 6.846

NAAS Rating: 3.77

weight of marketable roots. Also, yield was highly significantly and positively correlated $(\mathrm{R}=$ $0.53 *)$ with number of leaves. However, yield was highly significantly and negatively correlated $(\mathrm{R}=-0.57 *)$ with number of leaf area. In line with the result of our current study, Nedunchezhiyan et al. (2007) also found that number of tuberous roots per plant was strongly related to total tuberous root yield. Likewise marketable tuberous root yield is also highly significantly and positively correlated $\left(\mathrm{R}=0.97^{* *}\right)$ with total tuberous root yield. In line with the current study, Stathers et al, (2003) and Islam et al. (2002) showed that vine length, number of roots and root diameter were positively and significantly correlated with root yield (total root weight). Tsegaye et al., (2006) reported positive yet significant root girth among thirty sweetpotato genotypes. Selection of correlated traits influences each other thus allowing simultaneous selection in plant breeding programmes (Acquaah, 2012; Rukundo et al, 2013). Similarly, Yohhanes et al., (2010) reported that total storage root yield had significant and positive association with marketable storage root yield and average storage root weight. Gunjan (2012) also reported that marketable tuberous root yield was positively correlated with total tuberous root yield. This indicates that yield is an important agronomic index which shows adaptability of a genotype to its growing environment (Antiaobong and Bassey, 2008) and hence genotype Umuspo-3 can be identified as a high tuberous root yielding and adaptable genotype to the study area and also number of marketable roots and marketable root weight can be used as important factors for selection of sweetpotato to growers aimed at producing sweetpotatoes for tuber production and serves as an indicator of adaptability of the crop to the local growing conditions (Nwankwo et al., 2012).

\section{Principal component among yield and yield related characters of OFSP genotypes:}

Three main component axes (PC1 PC2 and PC3) were obtained in the principal component analysis in all ten (10) agro-morphological traits were studied (Table 5). PC analysis had eigen values up to 1.0 , explaining cumulative variance of $82.41 \%$ of the total variation among the genotypes (Table 5). The traits of importance for the first component involved root traits of commercial interest. Principal component one (PC1), with eigen value of 4.76, contributed $47.66 \%$ of the total variability. PC2, with eigen value of 2.39 , accounted for $23.91 \%$ of total variability. PC3, with eigen value of 1.08 , accounted for $10.83 \%$ (Table 5). In PC1, the traits that accounted for most of the $46.77 \%$ observed variability among the five genotypes included number of marketable roots, with vector loading of 0.88 , weight of marketable roots $(0.89)$, weight of unmarketable roots (0.62), yield (0.89) (Table 5). PCA is a technique to identify which plant traits is the most contributing to the observed variation. Afuape et al. (2011), who reported a cumulative variance of $76.00 \%$ for the first three axes in the evaluation of twenty-one sweetpotato genotypes, found important traits to be the genotypes they worked with. Four main components (PC) were identified, accounting for $67.22 \%$ of the total variation between accessions (Koussao et al., 2014). Placide et al., (2015) also used PCA to study the variability 


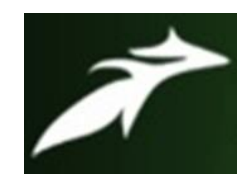

G. I. Harry et al, International Journal of Advances in Agricultural Science \& Technology, Vol.9 Issue.1, January-2022, pg. 22-36

ISSN: 2348-1358

Impact Factor: 6.846

NAAS Rating: 3.77

between 54 sweetpotato genotypes and found the cumulative variance of $77.83 \%$ from the first seven major component axes.

\section{CONCLUSION}

The current results showed that the most important yield and yield related characters: number of marketable root per plot, weight of marketable roots and storage root yield were significantly varied among the OFSP genotype evaluated in both cropping seasons. The highest marketable root weight per plot and storage root yield (29.22t/ha) were recorded from genotype Umuspo-3. Based on these results, Umuspo-3 recorded the best performance in the majority of yield and yield related characters and hence Umuspo-3 was preferably the best genotype compared to the other four OFSP genotypes. Yield is considered an important factor which determines choice of orange fleshed sweetpotato varieties for cultivation and it is also an important agronomic factors which shows adaptability of a genotype to the study area. Hence, genotype Umuspo-3 can be identified as a high yielding and adaptable genotype to the study area under the rain fed condition. Therefore, Umuspo-3 can be utilized as the best OFSP genotype with maximum yield and highest adaptability in Uyo agro-ecology of Akwa Ibom State and could be utilized to combat vitamin A deficiency in Akwa Ibom State.

\section{Conflict of interest}

Authors have declared that no competing interests exist.

\section{REFERENCES}

[1]. Acquaah, G. 2012. Principles of plant genetics and breeding. 2nd ed. Wiley-Blackwell, Oxford.

[2]. Afuape, S.O., Okocha, P. I. \& Njoku, D. (2011). Multivariate assessment of the agromorphological variability and yield components among sweetpotato (Ipomoea batatas (L.) Lam) landraces. African Journal of Plant Science 5 (2): 123-132.

[3]. Andrade, E.K.V., Carvalho de Andrade Junior V., Luiz de Laia, M., Cunha Fernandes, J. S., Oliveira A. J. M. \& Azevedo. A.M. (2017). Genetic dissimilarity among sweetpotato genotypes using morphological and molecular descriptors. Acta Scientiarum Agronomy 39:447-455.

[4]. Antiaobong, E.E. \& E.E. Bassey, (2008). Constraints and prospects of sweetpotato (Ipomoea batatas L.) production in humid environment of southeastern Nigeria. Proceedings of the second african regional conference on sustainable agriculture, (SARCSA'08), Governor's office Annex, Uyo, Nigeria, pp: 68-72.

[5]. Antiaobong, E.E., (2007). Life cycle, economic threshold and control of sweetpotato weevils, Cylas puncticollis Boh (Coleoptera: Curculionidae) in Akwa Ibom State, Nigeria. Ph.D. Thesis, Michael Okpara University of Agriculture, Umudike Nigeria, pp: 3-5.

[6]. County V (1996). Poultry manure as a source of nitrogen in potato production: part I. Agriculture and Aquaculture, Abstract

[7]. FAO (2015). Food and Agriculture Organisation of the United Nations-Crop Production Statistics. Available: http://faostat.fao.org/.

[8]. Food and Agriculture Organisation Statistics (FAOSTAT) (2014). http://faostat.fao.org/site/291/default.aspx 


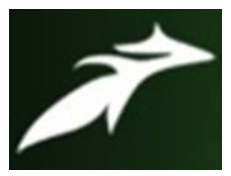

\section{G. I. Harry et al, International Journal of Advances in Agricultural Science \& Technology, Vol.9 Issue.1, January-2022, pg. 22-36}

ISSN: 2348-1358

Impact Factor: 6.846

NAAS Rating: 3.77

[9]. Gargi D.S., Porwal R. \& Shama R.K. (2013). Studies on growth, yield and tuber characteristics of sweetpotato varieties. Journal of Progressive. Research 8: 665-668.

[10].Gunjan, J., (2012). Increasing productivity of sweetpotato, Ipomoea batatas (L.) Lam through clonal selection of ideal genotypes from open pollinated seedling population. International Journal of Farm Sciences 2: 17-27.

[11].Islam, M.J., M.Z., Haque, U.K., Majumder, M.M., Haque, \& M. F. Hossain. (2002). Growth and yield potential of nine selected genotypes of sweetpotato. Pakistan Journal of Biological Sciences 5(5): 537-538.

[12].Kathabwalika, D.M., Chilembwe, E. H.C., Mwale, V.M., Kambewa D. \& Njoloma, J. P. (2013). Plant growth and yield stability of orange fleshed sweetpotato (Ipomoea batatas) genotypes in three agroecological zones of Malawi. International Research Journal of Agricultural science and soil science 3: 383-392.

[13].Koussao, S., Gracen, V., Asante, I., Danquah, E. Y., Ouedraogo, J. T., Baptiste, T. J., Jerome, B., \& Vianney, T. M (2014). Diversity analysis of sweetpotato (Ipomoea batatas [L.] Lam) germplasm from Burkina Faso using morphological and simple sequence repeats markers. African Journal of Biotechnology, 13(6), 729-742.

[14].Low J.W., Arimond M., Osman N., Cunguara B., Zano F \& Tschirley D. (2007). A food-based approach introducing orange-fleshed sweetpotatoes increased vitamin A intake and serum retinol concentrations in young children in Mozambique. Journal of Nutrition 137:1320-1327

[15]. Mcharo \& Ndolo (2013). Sweetpotato root-yield performance in Kenya 4914 Root-yield performance of pre-release sweetpotato genotypes in Kenya. Journal of Applied Biosciences. 65:4914 - 4921: ISSN 19975902.

[16].Mukhtar A.A., Tanimu B., Arunah U.L. \& Babaji B.A. (2010). Evaluation of Agronomic Characters of Sweetpotato varieties grown at varying levels of organic and inorganic fertilizers. World Journal of Agricultural Science 6(4):370-373.

[17].Ndaeyo, N.U., (2003). Growth and yield of maize (Zea mays L.), cassava (Manihot esculenta Crantz) as influenced by different tillage practices. Journal of Sustainability Tropical Agricultural Research, 8(1): 82 $-88$

[18].Ndolo P.J., Nungo R.A., Kapinga R.E. \& Agili S. (2007). Development and promotion of orange-fleshed sweetpotato varieties in Western Kenya. Proceedings of the 13th ISTRC Sympossium, Arusha, Tanzania, pp. 689-695

[19].Njoku, J. C., Muoneke, C. O., Okocha, P. I., \& Ekeleme, F. (2009). Effect of propagule size and intra-row spacing on the growth and yield of sweetpotato in humid agro-ecological zone. The Nigerian Agricultural Journal, 40 (1 and 2), 115-124.

[20].Nwankwo, I.I.M., E.E. Bassey, S.O. Afuape, J. Njoku, D.S. Korieocha, G. Nwaigwe \& T.N.C. Echendu, 2012. Morpho-agronomic characterization and evaluation of in-country sweetpotato accessions in southeastern Nigeria. Journal of Agricultural Science 4: 281-288.

[21].Omiat, E.G., R.E. Kapinga, S. Tumwegamire, T.L. Odong \& E. Adipala, 2005. On-farm evaluation of orange-fleshed sweetpotato varieties in Northeastern Uganda. Afr. Crop Sci. Conf. Proc., 7: 603-609.

[22].Placide, R., Shimelis, H. Laing, M. \& Gahakwa, D. (2015). Phenotypic characterization of sweetpotato genotypes grown in East and Central Africa. South African Journal of Plant and Soil 32:77-86

[23]. Robert SP (2012). Effect of Manures on the yield of two improved varieties of sweetpotato in Uyo Local Government Area (A case study of vocational Agricultural Education Research Farm, University of Uyo). Unpublished B.Sc (ed) Project, University of Uyo, Uyo.

[24].Rukundo P., Hussein S., Mark L., \& Daphrose G. (2015) Phenotypic characterization of sweetpotato genotypes grown in East and Central Africa. South African J. Plant and Soil. 32:77-86.

[25].Saviour, O. N., Okon, D. P. and Roberts, S. P. (2013). Comparative effects of chicken manure and NPK on the yield of Ipomoea batatas Journal of Agricultural and Crop Research (6), pp. 90-93. 


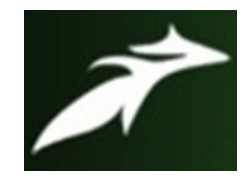

\section{G. I. Harry et al, International Journal of Advances in Agricultural Science \& Technology,} Vol.9 Issue.1, January-2022, pg. 22-36

ISSN: 2348-1358

Impact Factor: 6.846

NAAS Rating: 3.77

[26].Stathers, T. E., Ress, F., Kabi, S., Mbilinyi, L., Smit, N., Koizya, H. \& Jeiffrics, D. (2003). Sweetpotato infestation by Cylas species in East Africa. I. Cultivar differences in field manifestation and the role of plant factors. International Journal of Pest Management, 49, 131-140. http://dx.doi.org/10.1080/0967087021000043085

[27]. Thottappilly, G. \& G. Loebenstein. (2009). Introductory remarks. In The Sweetpotato. G. Thottappilly and G. Loebenstein (eds). Springer Science+ Business Media B. V. Springer, New York.

[28].Tsegaye E., Devakara Sastry E.V. \& Dechassa N. (2006). Correlation and path analysis in sweetpotato and their implications for clonal selection. Journal of Agronomy 5 (3): 391-395.

[29]. Wariboko, C. \& I.A. Ogidi, (2014). Evaluation of the performance of improved sweetpotato (Ipomoea batatas L. LAM) varieties in Bayelsa State, Nigeria. African Journal Environmental Science and Technology 8: 48-53.

[30]. Yohannes G., Getachew B. \& Nigussie D. (2010). Genotypic and Phenotypic Correlations of Root Yield and other Traits of Orange-Fleshed Sweetpotatoes [Ipomoea batatas (L.) Lam.]. Journal of the Dry lands 3(2): 208-213. 


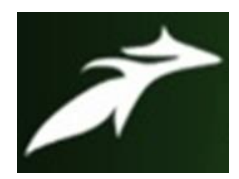

G. I. Harry et al, International Journal of Advances in Agricultural Science \& Technology,

Vol.9 Issue.1, January-2022, pg. 22-36

ISSN: 2348-1358

Impact Factor: 6.846

NAAS Rating: 3.77

Table 1: Description of the five orange fleshed sweetpotato varieties used as planting materials

\begin{tabular}{lllll}
\hline S/No. & Genotypes & Source & Storage root shape & $\begin{array}{l}\text { Predominant flesh } \\
\text { colour }\end{array}$ \\
\hline 1 & NASPOT-12 & NRCRI, Umudike & Elliptic & Intermediate orange \\
2 & UMUSPO-1 & NRCRI, Umudike & Long irregular or curved & Pale orange \\
3 & LOURDES & NRCRI, Umudike & Long elliptic & Pale orange \\
4 & ERICA & NRCRI, Umudike & Long elliptic & Pale orange \\
5 & UMUSPO-3 & NRCRI, Umudike & Round & Dark orange \\
\hline
\end{tabular}

Table 2: Mean square values for growth and yield characters of the five types of orange fleshed sweetpotatoes in 2020 cropping season

\begin{tabular}{lcccccccccc}
\hline Genotypes & $\begin{array}{c}\text { Vine } \\
\text { length }\end{array}$ & $\begin{array}{c}\text { Vine } \\
\text { girth }\end{array}$ & $\begin{array}{c}\text { Number } \\
\text { of } \\
\text { branches }\end{array}$ & $\begin{array}{c}\text { Leaf } \\
\text { area }\end{array}$ & $\begin{array}{c}\text { Number } \\
\text { of leaves }\end{array}$ & MRN & UMRN & MW & UMW & $\begin{array}{c}\text { Yield } \\
\text { (t/ha) }\end{array}$ \\
\hline UMUSPO-3 & 234.41 & 4.29 & 6.80 & 65.80 & 153.87 & 33.61 & 5.67 & 15.60 & 2.83 & 29.22 \\
UMUSPO-1 & 128.00 & 3.60 & 4.07 & 106.67 & 86.53 & 16.50 & 6.67 & 10.52 & 2.23 & 17.44 \\
ERICA & 153.73 & 3.10 & 5.00 & 98.18 & 93.27 & 21.33 & 7.00 & 8.53 & 2.73 & 14.63 \\
NASPOT-12 & 140.07 & 4.27 & 6.73 & 115.58 & 128.20 & 15.02 & 7.67 & 8.41 & 1.93 & 13.67 \\
\hline
\end{tabular}




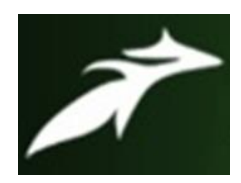

G. I. Harry et al, International Journal of Advances in Agricultural Science \& Technology,

Vol.9 Issue.1, January-2022, pg. 22-36

ISSN: 2348-1358

Impact Factor: 6.846

NAAS Rating: 3.77

\begin{tabular}{lcccccccccc}
\hline LOURDES & 147.66 & 3.81 & 8.53 & 124.48 & 101.80 & 18.45 & 5.00 & 5.42 & 2.27 & 9.56 \\
Total & 160.77 & 3.81 & 6.23 & 102.14 & 112.73 & 20.98 & 6.40 & 9.70 & 2.40 & 16.90 \\
LSD $_{(\mathrm{P}<0.05)}$ & 37.87 & $\mathrm{NS}$ & $\mathrm{NS}$ & 26.75 & $\mathrm{NS}$ & 2.86 & $\mathrm{NS}$ & 2.60 & $\mathrm{NS}$ & 3.57 \\
\hline
\end{tabular}

MRN = Marketable Root Number per plot, UMRN = Unmarketable Root Number per plot, MW = Marketable weight per plot, UMW = Unmarketable weight per plot 


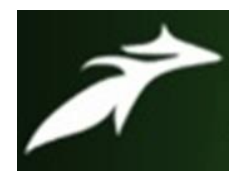

G. I. Harry et al, International Journal of Advances in Agricultural Science \& Technology,

Vol.9 Issue.1, January-2022, pg. 22-36

ISSN: 2348-1358

Impact Factor: 6.846

NAAS Rating: 3.77

Table 3: Mean square values for growth and yield characters of the five types of orange fleshed sweetpotatoes in 2020 cropping season

\begin{tabular}{|c|c|c|c|c|c|c|c|c|c|c|}
\hline Genotypes & $\begin{array}{c}\text { Vine } \\
\text { length }\end{array}$ & $\begin{array}{l}\text { Vine } \\
\text { girth }\end{array}$ & $\begin{array}{c}\text { Number } \\
\text { of branches }\end{array}$ & $\begin{array}{l}\text { Leaf } \\
\text { area }\end{array}$ & $\begin{array}{l}\text { Number } \\
\text { of leaves }\end{array}$ & MRN & UMRN & MW & UMW & $\begin{array}{l}\text { Yield } \\
\text { (t/ha) }\end{array}$ \\
\hline UMUSPO-3 & 252.80 & 3.70 & 8.20 & 85.49 & 137.73 & 34.78 & 5.33 & 17.27 & 2.17 & 28.78 \\
\hline UMUSPO-1 & 140.07 & 4.27 & 6.73 & 115.58 & 128.20 & 17.33 & 6.00 & 10.40 & 2.13 & 16.33 \\
\hline ERICA & 163.73 & 3.10 & 5.00 & 98.18 & 93.27 & 22.33 & 6.00 & 8.53 & 2.07 & 14.22 \\
\hline NASPOT-12 & 126.47 & 3.59 & 3.53 & 115.01 & 77.87 & 16.95 & 6.67 & 8.00 & 1.60 & 13.33 \\
\hline LOURDES & 147.66 & 3.81 & 8.53 & 124.48 & 101.80 & 19.62 & 4.67 & 5.33 & 1.93 & 8.89 \\
\hline Grand Mean & 164.15 & 3.69 & 6.40 & 107.75 & 107.77 & 22.20 & 5.73 & 9.91 & 1.98 & 16.31 \\
\hline $\operatorname{LSD}_{(\mathrm{P}<0.05)}$ & 38.59 & NS & NS & NS & NS & 3.18 & NS & 2.12 & NS & 3.54 \\
\hline
\end{tabular}

MRN = Marketable Root Number per plot, UMRN = Unmarketable Root Number per plot, MW = Marketable weight per plot, UMW = Unmarketable weight per plot 


\section{$\vec{x}$}

G. I. Harry et al, International Journal of Advances in Agricultural Science \& Technology,

Vol.9 Issue.1, January-2022, pg. 22-36

Table 4: Correlation of growth characters, yield and yield components in five sweetpotato genotypes

\begin{tabular}{|c|c|c|c|c|c|c|c|c|c|c|}
\hline Parameters & $\begin{array}{c}\text { Vine } \\
\text { length }\end{array}$ & $\begin{array}{l}\text { Vine } \\
\text { girth }\end{array}$ & $\begin{array}{c}\text { Number } \\
\text { of } \\
\text { branches }\end{array}$ & $\begin{array}{l}\text { Leaf } \\
\text { area }\end{array}$ & $\begin{array}{c}\text { Number } \\
\text { of } \\
\text { leaves }\end{array}$ & MRN & UMRN & MW & UMW & $\begin{array}{l}\text { Yield } \\
\text { (t/ha) }\end{array}$ \\
\hline \multicolumn{11}{|l|}{ Vine length } \\
\hline Vine girth & -0.163 & & & & & & & & & \\
\hline Number of branches & 0.392 & 0.441 & & & & & & & & \\
\hline Leaf area & -0.332 & 0.348 & 0.069 & & & & & & & \\
\hline Number of leaves & $0.602^{*}$ & $.0520^{*}$ & $0.662^{* *}$ & 0.128 & & & & & & \\
\hline MRN & $0.864^{* *}$ & -0.149 & 0.351 & $-0.598^{*}$ & 0.461 & & & & & \\
\hline UMRN & -0.061 & -0.279 & $-0.539^{*}$ & 0.249 & -0.323 & -0.234 & & & & \\
\hline MW & $0.729^{* *}$ & 0.130 & 0.240 & $-0.575^{*}$ & $0.538^{*}$ & $0.843^{* *}$ & -0.142 & & & \\
\hline UMW & 0.340 & 0.379 & $0.514^{*}$ & -0.004 & $0.661^{* *}$ & 0.358 & -0.472 & 0.381 & & \\
\hline Yield & $0.729^{* *}$ & 0.130 & 0.240 & $-0.575^{*}$ & $0.538^{*}$ & $0.843^{* *}$ & -0.142 & $0.998^{* *}$ & 0.381 & \\
\hline
\end{tabular}

*. Correlation is significant at the 0.05 level (2-tailed).

$* *$. Correlation is significant at the 0.01 level (2-tailed).

MRN = Marketable Root Number per plot, UMRN = Unmarketable Root Number per plot, MW = Marketable weight per plot, UMW =

Unmarketable weight per plot 


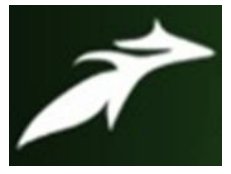

G. I. Harry et al, International Journal of Advances in Agricultural Science \& Technology, Vol.9 Issue.1, January-2022, pg. 22-36

ISSN: 2348-1358

Impact Factor: 6.846

NAAS Rating: 3.77

Table 5: Principal component analysis of five sweetpotato genotypes

\begin{tabular}{llll}
\hline & \multicolumn{3}{c}{ Component } \\
& PCA 1 & PCA 2 & PCA 3 \\
\hline Vine length & 0.823 & -0.257 & 0.2660 \\
Vine girth & 0.213 & 0.768 & 0.139 \\
Number of branches & 0.574 & 0.590 & -0.141 \\
Leaf area & -0.458 & 0.651 & 0.508 \\
Number of leaves & 0.754 & 0.499 & 0.293 \\
Number of marketable tuber per plot & 0.884 & -0.364 & -0.022 \\
Number of unmarketable tuber per plot & -0.407 & -0.417 & 0.766 \\
Weight of marketable tuber per plot & 0.894 & -0.291 & 0.130 \\
Weight of unmarketable tuber per plot & 0.623 & 0.488 & -0.093 \\
Yield & 0.894 & -0.291 & 0.130 \\
Total & 4.766 & 2.391 & 1.084 \\
\% of Variance & 47.662 & 23.914 & 10.839 \\
Cumulative \% & 47.662 & 71.576 & 82.415 \\
\hline & & & \\
\hline
\end{tabular}

